\title{
Rereading Finno-Ugrian Religion from a Gender Point of View
}

I intend to discuss the epistemological and methodological significance the perspective of gender has on religious studies. I will argue, along the lines commonplace within the gender studies in various disciplines, that the problem of women's invisibility is not only due to a casual oversight by male scholars, but it also has its roots on the conceptual level of the disciplines. The sources, concepts and models we work with are largely based on male experience and carry thereby a built-in androcentrism. The intrinsic androcentrism in our conceptual tools may result in a systematic exclusion of women and their experiences and practices from the scholarly studies of religion (cf. King 1995a: 19; cf. Moore 1988: 2 ff.; Code 1991: 60). Therefore it does not suffice to compensate for the absence of women by just 'adding the women and stirring' as the common expression has it, instead, a revaluation and revision of the whole "male paradigm" will be necessary. It implies critical scrutiny of the concepts and models as well as an attempt to bring to light the underlying assumptions, the tacit knowledge in Kuhnian terms, which has influenced and shaped male writing of religion.

I will illustrate the issue at hand by analysing the overviews in some central handbooks and entries in encyclopaedias (ERE, ER) on the Finno-Ugrian religions as well as the central monographs in the series Suomen suvun uskonnot (The Religions of the Finnic Peoples) on which these overviews are largely based. The reason I have chosen to study this type of data is that they play a central role in the socialisation of the students as well as a gateway for scholars into a particular religion. They serve also as a medium for internalisation of the central concepts and categories in the study of a particular religion. Furthermore, it is worth noticing that the university reading lists also communicate to students what constitutes relevant knowledge in religious studies (cf. Behar 1993: 314).

Judging from the lack of discussions of method in the literature under scrutiny the scholarly representation of religious phenomena 
has been considered quite straightforward and unproblematic. It seems as if religious phenomena were seen as objectively existing entities which the ethnographer faithfully documented and registered for later processing into a monograph (see e.g. Krohn 1894: 1). The belief in the objectivity of the scholarly representation is also implicit in Honko's characterisation of Harva's method, when that method was at its best:

In attempting to compose the most authentic possible picture of religious ceremonies by comparing different sources, Harva apparently learnt to respect good sources and gradually formed his own descriptive manner, in which information is grouped into a chain of facts and in which theorizing has little place. When a belief, custom or ceremony was well described the conclusions seemed to be almost self-evident. Even if the conclusions were not always sensational, this was better than squeezing out of sources what was not there. (Honko 1969-70: 60; italics mine).

The implication is that Harva managed to produce something that Van Maanen might call a realist tale, i.e. a tale with implicit claims of authenticity and value-freedom, a tale that anyone given the same sources or/and facing the same field would produce (cf. Van Maanen 1988: $45 \mathrm{f}$.). During the past decades the prior unproblematic view on ethnographic writing has been challenged and it is generally acknowledged that pure description does not exit, but that we are always dealing with an interpretation done from a certain perspective or perspectives. Even Harva's writing, in spite of his refraining from theorising, was not unbiased, but was guided by certain underlying assumptions and preconceived ideas. The assumptions that are of central interest for us here are his implicit gender conceptions. Though not recognised as an analytical category by previous research, gender constitutes in fact one of the perspectives which has to a large extent steered the production of knowledge within religious studies. Its significance has been until quite recently overlooked. The purpose of my study is therefore to reread the aforementioned monographs and overviews from the perspective of gender in order to examine how the scholarly conceptions of gender has steered the prior construction of Finno-Ugrian religion. The selection of religious phenomena which have been presented as central and general in a particular religion or religions is not the result of an objective study, but has to a certain extent been a matter of judgement made from a cer-

\footnotetext{
${ }^{1}$ Theory for Harva was the 19th century theories of the origin of religion.
} Honko 1969-70: 60. 
tain position within the gender system of a particular culture. I believe, it is in a higher degree than generally acknowledged, a matter of convention and evaluation what type of knowledge is considered relevant, i.e. worth recording and putting in the books.

A close study of the literature confirms one of the basic facts of women's studies; that the cultural complexes which are held to be central and general in a particular culture are largely representative of those of the male population. To somewhat radically rephrase Kaarle Krohn, one of the editors of the series Suomen suvun uskonnot and the author of the first monograph in the series, these representations describe the religion of Väinämöinen and his cousins from the countryside (Krohn 1914: 10). In spite of the fact that women were often banned from or were relegated to playing a marginal role in the alleged core complexes (e.g. bear ceremonialism, various sacrificial ceremonies, hero cult), these very instances have frequently been presented not only as central but even as general, i.e. as if engaging the whole population to the same extent and on equal terms (e.g. Honko 1968; Honko 1987: 332-4; Siikala 1987: 327 f.). The fact that women played an important role in ancestor worship hardly appears at all from the earlier descriptions (e.g. Harva 1964: ch 3, ch 4).

In order better to understand how these unbalanced representations have come about and attained a status as established knowledge we have to trace back the process of constructing religion in the history of research. It seems that Julius Krohn or rather his son Kaarle, who after his father's sudden death edited and complemented the first overview on Finno-Ugrian religions, namely Suomen Suvun Pakanallinen Jumalanpalvelus (The Pagan Worship of the Finnic peoples, 1894) set the pattern for later scholarship at least in two respects. Firstly, building on Castrén's work Krohn picked out the phenomena which were held to be common and original to Finno-Ugrian religions (Krohn 1894: 1; Krohn 1914: ch 3, ch 4; Harva 1996: 18). As Anttonen has mentioned, Krohn's work served again as a model for Harva, when writing his early study, that of the Saami religion (Anttonen 1987: 109). It has also influenced his later production, even though Harva did not follow Krohn slavishly and uncritically. The central religious complexes, introduced by these scholars have been faithfully reproduced by the later scholarship on the religions in question.

Secondly, Krohn's work also created the androcentric pattern which has implicitly directed subsequent research. The Finno-Ugrian Urreligion, the scholars sought to reconstruct, seems to have been predominately male religion, where women had quite a marginal position. The literature frequently presents women through negation. 
Even the monographs which do include an occasional chapter on women, present them as objects of taboos, impure and even unholy (Karjalainen 1921: 50 f.; Karjalainen 1927: 235 f.; Lehtisalo 1924: $110 \mathrm{f}$.). The instances where women were observed to play a central part were either explained away as late development or they were disregarded as foreign influence, irrelevant to those who were involved in the project of reconstructing original Finno-Ugrian religion.

The scholarly treatment of women as marginal in the religious descriptions is in agreement with the oft-observed fact in women's studies that men are seen as the norm and women are just an exception to this norm. The title of Karjalainen's chapter Die Sonderstellung des Weibes is a good example on androcentric thinking, where women are just treated as a special case (1927: 235). This, of course is quite logical since the "normal subject", the scholarly writing of religion presupposes, is based on male experience (cf. Rosenhaft 1997: 23 f.; King 1995a: 19). Thus, the challenge the gender perspective offers to religious studies, metaphorically speaking, is not just the complementing of Väinämöinen's religion with that of his female counterpart Louhi. ${ }^{2}$ As this asymmetrical juxtaposition already indicates, the gender perspective has much more profound consequences on the epistemology and methodology in religious studies. It necessitates the deconstruction of the male "normal subject" underlying the scholarly representations. The male "normal subject" has served as the basis for conceptualisation and classification. Androcentrism, which is built into the very tools of our discipline has led to a systematic exclusion of women's experience and practices from the phenomenological descriptions and presentations and is constantly reproduced through the "canonic" literature of encyclopedias, handbooks and classical monographs (cf. King 1995b: 235 f.).

In the following I will analyse in greater detail some aspects of the process of knowledge production in order to show in more concrete terms how androcentric knowledge has been generated and how androcentrism has influenced our religious constructs.

\footnotetext{
${ }^{2}$ It is interesting to note that the antireligious activists in Soviet Karelia actually used Louhi as a symbol of women's "superstition". They defined their goal as expelling Louhi, the woman of the North, from Karelia, "who still with her spells [and] her church keeps the Karelian women in darkness..." Karjalan kommuuni 1922: 5.
} 


\section{Engendering androcentric knowledge}

Fieldwork by Finnish scholars among the Finno-Ugrians and Samojeds was principally conducted by male philologists and ethnologists. It was only in 1929 that the Finno-Ugrian Society sent out its first female grant holder. She collected plant names in Estonia (Ravila 1933: 31). Women's activity within Finnish folkloristics and ethnology was roused in the end of 1920 's, but their actual breakthrough was only after the war (Turunen 1996: 78). The primary goal of philologist-ethnographers was systematically to study and register the language they set out to study, but they also produced on the side monographs on mythology and religion. The travel reports draw a dramatic picture of the encounter between the fieldworker and the suspicious locals. Occasionally the researcher was associated with the feared Russian authorities or as the case was with Paasonen, he was believed to represent the Antichrist himself (Paasonen 1900: 2, 5). Thus, the barrier was high between a male researcher and the local men, but it was even higher between him and the local women (e.g. Karjalainen 1983: 58 f.; Balzer 1978: 103, 108). The fieldworker's sex was a concrete hindrance, which did not allow him access or insight into women's religion and culture. The existing sources on the FinnoUgrian religions are thereby to a great extent a result of negotiations between a male scholar and a male informant-instructor, the latter, at least in the beginning often quite reserved and unwilling to cooperate, particularly in religious matters. Sometimes the local authorities more or less commanded a person to function as an instructor to the researcher (Karjalainen 1983: 144; see also Korhonen, Suhonen and Virtaranta 1983: 66, 71, 141).

It can be considered quite peculiar that the researchers ignored women as language instructors since women, being more bound to home would to a higher degree have preserved their language from foreign influences. Also the guide for Finnish dialect collectors (1924) did acknowledge women as better instructors, even though the collectors were warned about women's smaller ability of abstraction (Hakulinen 1924: 9; Kosonen 1988: 289). In the instructions for his lexical questionary 1931 Kai Donner defines the characteristics demanded of an informant as follows: "As a language instructor a suitable middle-aged, ca. 25-55-year-old, male person should be chosen everywhere, one who lives in the dialect area in question and either lives off the land or has lived off the land."

\footnotetext{
${ }^{3}$ SK 1.
} 
Since the issue of gender is our topic here I will not ponder upon how the hierarchical and complex relationship between the fieldworker and informant affected the data collection and the subsequent ethnographic writing. Suffice it to say that the fact that women themselves were hardly consulted at all proves to be quite fatal when studying cultures, such as those of the Finno-Ugrians, where the gender systems were dualistic and complementary. Much information on women's religious ideas and practices has been left out or was attained through male informants. ${ }^{4}$ Anthrocentrism has thereby been built into our source materials. Even if the male bias has been corrected somewhat by later research, which to a greater extent has focused on women, ${ }^{5}$ our sources are lacking and the reconstruction of women's religion may seem a hopeless task. Since we cannot undo the scholarly oversight in the past and fill in the gaps, we are forced to settle with Gross's (over-?) optimistic claim that a complementation of sources with new materials is not an absolute necessity for a more balanced writing of religion. The problem according to Gross is not so much the lack of data but rather the prior evaluation of it by the scholars. She claims that the existing information has "been either overlooked or interpreted as evidence that women are unimportant, minor participants in a male-dominant society" (1996: 66). Since the evaluative and ideological elements seem to have played an important role in construction of religion I therefore find it necessary to examine in more concrete terms how a male scholar's frame of reference has steered the production of religious knowledge.

\section{The male paradigm}

As Harri Englund among others has pointed out the ethnography discussion has to a surprisingly great extent overlooked the importance of theory in ethnographical writing (1989: $28 \mathrm{f}$.). We can agree with Berreman, who maintains that "there can be no pure observation and no straight description without underlying assumptions without a theory or theories - which determine what will be observed and what will be recorded." Therefore "all observation is se-

\footnotetext{
${ }^{4}$ For more detailed discussion of the double male bias, see Ardener 1975: 4 f.; Nenola 1986: $31 \mathrm{f}$; Moore 1988: $3 \mathrm{f}$.

5 I refer here particularly to the Russian scholars' growing interest in women's religious practices among the Finno-Ugrian peoples. See for example the conference publication Congressus Octavus Internationalis FennoUgristarum 1996.
} 
lective and all recording of observation is selective again." (Berreman 1968: 339; also Moore 1988: 4). In the following I will briefly discuss some of the basic assumptions and implicit theories which, I believe, have directed the process of constructing Finno-Ugrian religion all the way from field observation and/or archive studies, through selection of relevant data to the composition of the final product, a monograph on a particular religion or religions.

Judging from the writing of some central figures within the early Finnish religious studies, particularly Julius/Kaarle Krohn and Uno Holmberg-Harva, they all seem to share a commonly held axiomatic notion of women's limited participation in the religious practices among the Finno-Ugrian peoples. When dismissing a description in a Scandinavian tale of a temple on the Western shore of the river Dvina as fiction, Julius Krohn's criterion for dismissal was the central position the tale ascribed to women at the temple. The tale had it that the temple was guarded by "tens of witches" (noita-akkoja) and its female care-taker was of the size of a giant. Krohn judges the tale to be unreliable as a source on Finnic religious practice, not because of the caretaker's exaggerated size, which indicates that we are dealing with a mythical tale, but, because women were depicted as priestesses and servants at the temple. According to him this description is not in accordance with the notion he claims to be general among the Finnic peoples, namely that women defile a holy place (Krohn 1894: 15). The numerous references to women as various kinds of functionaries later in the same book, which actually contradict his generalising statement, passed by unheeded by him. Holmberg-Harva elaborated further upon the notion of women's "unholiness" in his article Naisen seremoniallisen epäpyhyyden alkuper $\ddot{a}$ [The Origin of Women's Ceremonial Unholiness] from 1910. He opens his paper with the following assertion:

It is a fact that many former and existing peoples still hold that it is inappropriate for creatures such as women to approach a holy place or participate in any sacred act that implies worship. This conception we will find especially among the nature peoples, but traces of it have been preserved even among the more developed religions (Harva 1910: 623; translation and italics mine).

Holmberg-Harva does not question the accuracy of the above statement. Quite the contrary, it is proposed by him as a general truth. What he finds debatable is only the prior explanations by different scholars for the notion of women's "unholiness". His entry on the priests and priesthood among the Finno-Ugrian peoples in ERE proceeds in a similar vein: "[w]omen, as a rule, could not take part in the 
sacrificial service, and were deemed unworthy of the priestly office." (Harva 1918: 336, italics mine). Harva's generalising statement is somewhat contradictory since he admits in 1914 that among the Votiaks (Udmurts) women, at least in the more archaic regions, were allowed to take part in the sacrifices at home. He even mentions that there were particular functionaries, both male and female, at such feasts (Harva 1914: 85; Harva 1964: $130 \mathrm{f}$.). In spite of this, the assumption of women's exclusion from the religious sphere as "unholy" or "unworthy" runs through most of the series Suomen suvun uskonnot despite some evidence on the contrary in the books. Harva's monograph on Mordvinian religion (Harva 1942), where the feminine element was particularly strong, is a case in point. He describes a number of ceremonies where women actually played a central role, such as the "old women's porridge feast" (Das Altweiberbreifest, baban kaša) and "women's bratšina", i.e. "women's beer feast" (1952: $365 \mathrm{f}$., 386). Harva found the fact that Mordvinian women acted as prayer-leaders in a number of sacrificial ceremonies quite extraordinary. Since this observation did not agree with his conception of women's marginal role in religious practices, in order to save his view, he refuted these instances as being atypical of Finno-Ugrian religions and accorded them to "foreign influence", coming from the Russian side (1952: 419). It is symptomatic that he explains these ceremonies either as being of Russian origin or at least influenced by the Russians on the basis of the feast's Russian name and the Russian "tone" in the sacrificial prayers, while he at the same time had to admit that there was no evidence on baban kaša (women's porridge) type of feast among the Russians (1952: 380, 419). It is interesting to note that Paasonen, whose field notes and writing Harva largely has built on, is much more nuanced as far as women's roles in ceremonies were concerned in his article on Mordvins in ERE. Paasonen, unlike Harva, makes no reservations when presenting both men and women as sacrificial priests. He also points out that "[i]n some of the sacrificial feasts both sexes took part, but there were also distinct festivals for males and females respectively" (Paasonen 1915: 847). However, clinging to his conviction of women's marginal role Harva omitted these feasts from his overview on Finno-Ugrian religions in The Mythology of All Races (Harva 1964), where he just concentrates on the great feasts. Neither does Pentikäinen mention these ceremonies in his overview on Mari and Mordvin religions in his article in ER (1987) nor Honko in his overview on Finno-Ugric religions in ER (1987). It is first Siikala, who reinstalls this feast and women as sacrificial functionaries on the religious scene of the Mordvins in her entry on Finnic Religions in ER (1987: 328 f.). 
Eleanor Leacock, among others, has thrown light on the significance the scholar's preconceived ideas, attitudes and evaluations may have on his representation of native religious ideas. She mentions as an example the different values laid in the concepts "menstrual hut" and "men's house". The menstrual hut bears negative connotation of impurity and perhaps even suppression, while the concept "men's house" is associated with authority and respect (cf. Leacock 1972: 40). Even the female scholars, who have been socialised in a malest research tradition may take part in the reproduction of androcentrisms as Balzer's critique of Rombandeeva shows (see also Fox 1987: 564, 571). The latter calls the place were a newborn's old cradle was hung as "the most 'impure' spot". Balzer's female informants, on the other hand, insisted on calling the place the female counterpart to exclusive men's sacred groves (Balzer 1978: 84; Rombandeeva 1968: 81). Bäckman has criticised Lehtisalo, who depicts the Tundrajurak images of women's tutelary deities as 'unclean', on similar basis, but she misses the point somewhat when she claims that the conceptions of 'danger', associated with these objects and places, were reciprocal. Meaning that "women had to be careful about certain places and actions while a man had to be careful about others." (Bäckman 1982: 151; Lehtisalo 1924: 111). For the first, we cannot simply equate impurity with danger as Bäckman does, even though these notions are interconnected. Secondly, there is an asymmetry in the reciprocal avoiding of certain places and things as Rydving has observed. Saami women, for example, were forbidden to tread the male religious sphere at any time, while men were banned only during sacred time (Rydving 1993: 146). It was the power emanating from women's bodily states, which made women and their domain dangerous to men. Thus, women in fertile age periodically embodied danger, whereas men were not in general thought to 'pollute' or otherwise threaten women or their sacred places.

These examples show clearly the significance the scholar's frame of reference and the perspective from where s/he studies the phenomena has on the interpretation of the religious phenomena, especially when we are dealing with the highly relative concept of impurity. If Hanti women's groves or objects were impure and dangerous from the male point of view, they were not so from women's, but, were instead perceived sacred by women (Balzer 1978: 84; Nenola 1993: 362). A scholar's undue fixation on the concept of impurity could even lead to sheer misinterpretation of women's religious practices. Harva, for example, depicts the porridge Saami women ate after a successful parturition as a purification meal and the eating ceremony as a purification ceremony even though he quotes Jessen in the next sentence 
asserting that the celebration was arranged in honour of the birth goddess Sarakka (Harva 1996: 68; Harva 1964: 253).

It seems that Westermarck's critique, presented at his lecture in 1911 , of the negative and generalising scholarly views on women's position in "cultures of lower level", went unheeded by Finnish students of religion. According to Westermarck, explorers had seldom supplied detailed presentations of the rights and duties of women among the people they described. Quite often their reports were contradictory, even in the work of the same author (Westermarck 1991: 16). As a matter of fact, it would take more than a half a century before Westermarck's point that religion did not just imply restrictions for women, but could also serve as a source of power, would be observed in Finnish religious studies (Westermarck 1991: 33; Nenola 1986: 51 f; Apo 1995). A more balanced writing of religion would demand an approach where women are also seen as subjects within the religious sphere.

Due to the preconceived ideas or "general truths" on women's impurity and unholiness held by the leading scholars, women's marginality in the sphere of religion became an integrated part of the source materials and in the descriptions based on those very materials. The researcher ended up in a vicious circle where women's exclusion from the sacred sphere became a self-fulfilling prophesy. The ethnographer perceived what his preconceptions led him to perceive and his constrained perception came again to confirm his preconceived ideas. By shutting women out of the sacred places because of their alleged impurity and unholiness, Krohn and his followers came to establish the status of the Finno-Ugrian women as profane, 'outside the fane', 'sacred place' (King 1987: 282). Thereby this basic axiom came also to motivate and even sanction women's exclusion from the subsequent scholarly overviews on Finno-Ugrian religions.

\section{Gender ideology and the selection of the core elements}

The persistent idea of women's marginality in the Finno-Ugrian religions is even more peculiar if we view women's religious roles from the perspective of the dominating contemporary theory, namely manism. Since ancestor worship was supposed to have its roots in the Finno-Ugrian Urreligion (e.g. Krohn 1913: 23) and since women played a central role in ancestor worship it would have been quite logical to expect that women were assigned a position in the $U r$ religion which was congruent with her actual role in the ancestor cult. This, however, was not the case, quite the contrary. Firstly, as 
already noted, women's role in ancestor worship seems to have gone unobserved by the early scholarship. Secondly, Holmberg actually derives the origin of women's exclusion from holy places from manistic ideas, namely from a fear for the spirits of the dead, who seek to intrude a women in order to get reborn (Harva 1910: 625, 627 f.). The fact that women's role in the ancestor cult was not acknowledged has also to do with the fact that this cult was an important element in the construction of national identity. Herderian nationalistic philosophy simply did not include women's traditions in a nation's cultural heritage (cf. Sawin 1990: 61; Fox 1987; also Utriainen 1995: 533 f.).

We could, of course, surrender to the generally held notion that women's exclusion from the scholarly accounts is simply based on the fact that women actually did not participate in the most significant religious practices in society. Likewise, we could explain the absence of female religious functionaries in the scholarly descriptions simply with the fact that there were no important female functionaries. One of Honko's criteria for a religious specialist is actually the "performance of an important function in the religious community." (1978: 85). The criterion of importance, however, begs the question who, and on what basis, has interpreted a certain ceremony or function as important (Gross 1996: 67). It also raises a further question why female functionaries and women's ceremonies, which, as the literature shows, have existed, have not been considered important and allotted the space in the literature they might deserve.

In order better to understand the persistence of the scholarly conviction on women's marginality within the religious sphere, we have to look for its roots in scholars' gender ideology and evaluations. This means that we have to take Leacock's and other scholars' critique of Western scholarship seriously. She criticises it for the tendency to interpret all cultures in terms of categories derived from their own society, for their failure to see women as actors on the scene of human history as well as for taking the hierarchic gender relationship, typical of their culture for granted even when studying foreign cultures (Leacock 1983: 263, 266). As appears from Bäckman's article on women's position in religion and society in Northern Eurasia also the source-writers as well as students of Finno-Ugrian cultures have made themselves guilty of imposing their gender ideology and hierarchies on the data they have studied (1982: $151 \mathrm{f}$.). Therefore our deconstruction project demands a closer study of the implications such an imposition might have on the actual representations of women within these religions. For the first we have to examine how the underlying principles that have governed the scholar's gender system have directed his study of cultures with different type of gender sys- 
tems. I will take my point of departure in Hirdman's already classical model, though, bearing Leacock's critique in mind, I will mainly apply it to scholarly thinking in order to avoid the imposition of western feminist hierarchies on our complex data. Hirdman has identified two underlying principles in a gender system: Firstly, that of the gender dichotomy, i.e. the norm of keeping apart the male and female categories. Secondly, the principle of hierachy: men are the norm for the normal and the universal. These two principles, I believe, also were fundamental in the scholarly way of thinking and evaluating gender and they have on the conceptual level steered the scholarly observation and construction of religion. The gender dichotomy which is of vital interest here is the division of space into male/public and female/private spheres. These two spheres are perceived as standing in a hierarchical relationship to one another, the public/male holding primacy over the private, acquiring a normative position over the latter. Since the scholar as a representative of the public sphere holds the precedence of interpretation, he assigns this sphere the official reality whereas the private, female sphere is seen to represent the unofficial (cf. Hirdman 1988: 51 f; Svalastog 1997: 46). This division has been of fundamental significance for the position women have been assigned in scholarly representations, not only in religious studies, but in cultural studies in general. Since the male/mainstream version of cultural history has been based on events that take place within the public, official sphere, women have become invisible in the writing of history (Saarinen 1992: 122; also Gross 1996: $67 \mathrm{f}$.). From the man-as-a-norm principle it follows that the events within the male public sphere were not only considered more significant and important in a society than those in the private sphere, but they also were seen as representative and typical of the entire culture. And conversely the events within the private sphere were seen as insignificant in their assumed particularism.

When applying our model to the study of Finno-Ugrian religions it is obvious that the elements that have been presented as central are those which took place within the public/male sphere. It is obvious that male practices have been perceived as general and even typical of a given religion and have been presented as such. The spectacular sacrificial feasts of Volga Finns or the great bear feasts of $\mathrm{Ob}$ Ugrians, gathering great numbers of spectators from miles away, are bound to be interpreted as central and even typical of that particular religion, even though they might only have taken place with an interval of several years and might only have involved part of the population. Spectacular and exotic events within the public sphere were bound to catch the eye of the researcher and would be inter- 
preted as significant and important, while women's less conspicuous, but from their point of view not necessarily less important, events could pass unnoticed and unrecorded. A woman's preparing a sacrificial porridge might not have been interpreted as a significant religious act since this activity could be associated by the researcher, due to his cultural background, with the humdrum of secular every day life. ${ }^{6}$ Women's religious practices, which seem to have been intertwined with their daily chores and their nurturing roles could be seen as extension of these chores and roles, would therefore be less liable to draw the attention and interest of an ethnographer.

Since men were observed to act on behalf of the whole group at public ceremonies, they were also thought to represent women in religious matters in general. This view, of course fails to recognise the existence of ceremonies where women played an active role as well as it ignores the fact that women's religious practices, which indeed tended to be of more private nature, from which men sometimes were strictly forbidden, also served the whole community, not just women's private ends. Furthermore, women's religious activities were by no means limited to the private sphere as this division of space falsely leads us to understand.

\section{Androcentric classification of religious functionaries}

The above-mentioned idea of the gendered spheres has been so fundamental and rigid that when observed to be inconsistent with social reality, the inconsistency has not invoked redefinition of the gender of the spheres, but instead, leads to redefinition of gender characteristics and roles of the human actors who operate on the "wrong" side (cf. Svalastog 1997: 46). From this it follows that women's activities as religious or ritual functionaries in the public sphere did not call into question the common perception of the public sphere as male. Instead, women's activity within the public sphere, was accepted, but was preconditioned by a redefinition of their gender characteristics or/and their gender roles. In other words, women in public roles were treated by the community as well as the scholar as social males or 'honorary men.' It is well known that it was mostly old, postmenopausal women, who, due to their natural bodily changes stood closer the category of males, were allowed to participate in men's re-

\footnotetext{
${ }^{6}$ For a more detailed description of the nature of women's sacrificial feasts, see Heikkinen 1992.
} 
ligious ceremonies and who also acquired roles as religious specialists (Vilkuna 1956: 175; Balzer 1978: 128). As Shirley Ardener has pointed out " $[t]$ he old may do things or exhibit characteristics, or lack certain features, which by definition women do not do, or do not have, or should have. /--/ [T] hey may have lost the 'specificity' of women, and are therefore reclassified by their 'general', man-like characteristics." (Ardener 1993: 26, italics mine). Ardener's assertion coincides with that of Karjalainen's informant, who explained old women's extended rights to participate in the men's ceremonies as being due to their no longer doing "the doings of women." (Karjalainen 1927: 241; Balzer 1978: $129 \mathrm{f}$.). The fact that women only seem to have acquired their "civil rights" in religious matters at an old age, to use Karjalainen's term, explains why scholars might have felt themselves justified in treating female religious functionaries as exceptions.

The idea of a man as a key religious functionary has been so fundamental to scholars, who had a background in a religion where women did not possess such roles, that they did not always recognise the existing female functionaries as such. Since the scholarly classifications of religious functionaries were based on the male "normalsubject," female functionaries fell outside the narrowly defined categories or had their gender characteristics redefined in order to fit in. In Finnish research women did not quite match the scholarly idea of tietäj $\ddot{a}$, 'seer', since it seems that the male tietäjä-heroes in Kalevala had led to the quite common conception of proper tietäjä as a "bearded male". Above all, Väinämöinen has served as the model for scholarly and popular notions of tietäjä and was finally canonised by Haavio as a prototypical wiseman (Haavio 1952). A "bearded male" as a prototype made a wisewoman appear in the eyes of the scholars as a deviation from the ideal (cf. Gröndahl 1997: $44 \mathrm{ff}$.). Consequently, in an article in Kotiseutu, titled "Special people", a wiseman was depicted in positive terms as a kindred spirit (hengenheimolainen) of Väinämöinen, personifying the spirit of our forefathers (I. M. 1913: 6), whereas a wisewoman was deprived of her feminine attributes so that she would better fit into the class of tietäjäs. The writer implied that one Kaisa Pöyry, whom he believed had been beautiful in her youth, had become ugly, even scary in her old age because of her occupation - tietäjä "mysteries" had made her eyes to bulge and roll in her head (Tikka 1913: 5).

In cases where women's actual roles were not in agreement with the scholar's views on proper gender characteristics and gender roles, i.e. were not considered feminine enough, these roles were either ignored or played down by the scholar. In cases where a scholar had a choice he could emphasise the role that better matched his ideas and 
expectations. Since the roles of singer and lamenter agreed well with the scholarly idea of femininity, i.e. with women's alleged emotionality (see Utriainen 1995; Utriainen 1998), there has been a certain tendency to foreground women in these roles, while women in their allegedly unfeminine roles as powerful, "raging" seers were left in the background. Outi Lehtipuro has noted that the contemporaries of Mateli Kuivalatar, the principal singer of Kanteletar songs, would not have recognised her in Haavio's characterisation of her as a rosa carelica or as the "Muse of Finland" (Haavio 1985: 136). Quite contrary to the idea of ethereal poetess, she was known in her community as a powerful wisewoman and sorceress (Lehtipuro 1968: 144; Järvinen 1980: 143). In a similar manner, Toarie Huovinen, a "strong (vankka) tietäjä", whose knowledge and power was inherited by her grandson Miina Huovinen, widely known as a great tietäjä (suurtietäjä), is primarily presented by the scholars in her role as the ancestress of the well-known tietäjä-family (Haavio 1985: 84; Niemi 1921: $1094 \mathrm{ff}$.).

Also other female religious functionaries were ignored by the scholars as exceptions since they did not fit in the classificatory system, which was based on the practices of male functionaries. Harva's indifference towards the Mordvinian female sacrificial leaders could be explained by him not perceiving them as proper sacrificial leaders. These women certainly acted as ceremonial leaders, but did not themselves slaughter the animal when such a sacrifice was to be performed, but this was done by a male assistant (Harva 1952: 367, 371). The same might be the case with female shamans. According to Czaplicka a Yurak Samoyed shamaness was debarred from offering sacrifices to the domestic gods and did not act as religious leader in ceremonies (Czaplicka 1920: 174). Since the duties of these female religious functionaries differed from the male prototype these women might not have been considered proper sacrificial leaders or shamans.

\section{Redefining female functionaries}

The aforementioned Western scholarly tendency towards hierarchical thinking might also have led to a one-sided focusing on the important "big guys", i.e. on the great shamans and their "successors", tietäjäs, taltós, tunos etc., while female religious practitioners as well as "lesser" male functionaries, were ignored in their presumed insignificance. The assumed insignificance of female functionaries comes forth for example in the tendency to treat them as an anonymous 
collective. Harva constantly refers to the aforementioned Mordvinian female ceremonial leaders simply as "a woman", "a woman versed in the matter" (muuan asiaan perehtynyt akka), or a "couple of women". We learn first from Harva's summary on the special traits of Mordvinian sacrificial customs that these women also bore special titles, such as a "sacrificer", "adorer" (Opferin, Anbeterin), which would seem to imply some sort of specialist role (1952: $414 \mathrm{f}$.).

This one-sided focusing on important "big men" might also have inhibited the development of a varied and more comprehensive typology of religious functionaries. As pointed out already, the consequence of the fact that the scholarly typologies are to a great extent based on male practice, is that female functionaries would not readily fit into the "male" classes, falling either outside of the classificatory system or would get distorted if pressed into it. As a good example we could mention midwives, who performed important religious functions, but have nonetheless been left out of the scholarly classifications and accounts.

Furthermore, the scholarly emphasis on the "big guys" might also result in a hierarchic pattern being imposed even where no such pattern existed. It is fully possible that these functionaries were not always perceived by the community as being at the top of the hierarchy, but were considered more as a primus inter pares. This would have particularly serious consequences for studies in women's religion if we accept the somewhat controversial view that women do not define themselves within the general hierarchical system of society, but rather within their social network of weblike relations. Supposing that women's religion was less organised in hierachical terms, emphasising social connectedness, it would consequently not be possible to classify female functionaries in Western hierachical terms. They would simply fall outside the major scholarly pigeon-holes, where the ordering principles were authority and autonomy (cf. Ozorak 1996: 18). Seen in this non-hierachical perspective Harva's treatment of Mordvinian female ceremonial leaders as an anonymous group would be understandable, since they might not have stood out in a crowd as authoritative, autonomous leaders. This would go also for the Karelian and Russian anonymous term babkas for old women, who on the village level practised healing and midwifery.

I will illustrate the problem hierarchical thinking might lead us with an example from my own work. My inquiries into health care practices of some elder Russian Karelian women did not lead to a proper understanding of their health behaviour. My understanding of their choices of healers was undermined by my very inclination to view these functionaries in a Western hierarchic order. In spite of my 
ambition on value-free and sympathetic frame of mind, I had difficulties in appreciating the women's choice to consult a traditional healer instead of a doctor in cases where my experience told me that biomedical expertise would have been vital for the well-being of their children. In other words, I denied the babkas their status as healers, since my norm for a proper healer was an university-trained doctor. Unlike me, these women did not see the relationship between the doctor and the traditional healer in hierarchical terms, i.e. that the doctor was superior due to his expert training in medical matters, but instead, in equal and complementary terms. These women were quite convinced, on the basis of their experience, that doctors were superior in healing some illnesses, while the "grannies" were more competent in healing some others. Also their definition of competence differed from that of ours (Keinänen 1998: 198 f.).

As some historians have argued, we should refrain from viewing medical functionaries in traditional societies in the light of modern Western criteria on specialisation and professionalism, since most health practitionaries in non-Western societies, particularly women, would fall outside the scope of a definition based on the conventional and narrow concept of profession (e.g. Pelling 1987: 99 f.; cf. Green 1989: 444 ff.). Their point is also relevant when defining religious specialists within the frame of professionalism, as we can see from Honko's attempt to determine the status of lamenter as a religious specialist. Honko defines a religious specialist as a person, 1) who has a superior command of a specific tradition and 2) who performs an important function in the religious community. Since in certain regions the "best" lamenter did not always perform, but precedence was given to a person within the family, Honko finds it questionable whether the lamenter in these cases fill the social criteria of a religious specialist (1978: 85). Family members do not fall under the definition of professionalism, which emphasises the functionary's autonomy or social distance (cf. Pelling 1987: 104). Since we would even face the same problem of definition with other female specialists, for example midwives and healers, the former in some regions also specifically chosen within the extended family, we have to reformulate the criteria so that they would better agree with the social conditions of the cultures studied. I would suggest a following definition: A religious specialist is a person who was consulted as a religious functionary in their communities, either within the extended family or outside of it (cf. Pelling 1987: 99 f.; Lindemann 1993: 177) and who possessed, not necessarily superior knowledge, but sufficient knowledge demanded by these duties. This latter qualification is necessary since it is feasible that there are several persons on the same 
level of competence and that the criterion of choice was not only the superior command of tradition, but social qualities and relationship could weigh as much in the choice of the functionary. A wide definition also makes it possible to include Harva's women "versed in matters" in the class of religious specialists. The same would also go for the Mordvinian male practitioners whose status as sacrificial priests has been questioned, because of the low degree of institutionalisation of their practices.

\section{Conclusions}

The male "normal subject" underlying the prior religious descriptions has been constructed in two intertwining processes. Firstly, the scholar, by focusing on men's ideas and practices in the culture he has studied, has created concepts, models and a classificatory system for religious phenomena, which tends to exclude and distort the phenomena which are based on women's perhaps differing ideas and practices. Secondly, these ideas and practices have been filtered through the male scholar's frame of reference. His ethnocentrism and preconceived ideas as well as the tendency to view his object of study in hierarchical terms has coloured the phenomena studied as well as his overall religious constructs. The challenge of the gender perspective on religious studies is to deconstruct the male normal subject and to elaborate more nuanced and comprehensive models and classificatory systems which also would encompass women's religious ideas and practices.

\section{References}

Unpublished sources

Helsinki

SK 1 Sanakirjasäätiö (The Lexical Archives of Finnish Dialects) Ohjeita sanastomaantieteellistä kyselyä varten. Sanakirjasäätiön tiedusteluja 16.6. 1931. [stencil]

\section{Published sources and literature \\ Anttonen, Veikko}

1987 Uno Harva ja suomalainen uskontotiede. Helsinki: SKS. (Suomi, 138) Apo, Satu

1995 "Ex cunno väki tulee." Fyysiseen naiseuteen liittyvä ajattelu suomalais-karjalaisessa perinteessä. In: Satu Apo (ed.), Naisen väki: Tutkimuksia suomalaisten kulttuurista ja ajattelusta; pp. 11-49. Helsinki: Hanki ja jää. 


\section{Ardener, Edwin}

1975 Belief and the Problem of Women. In: Shirley Ardener (ed.), Perceiving Women; pp. 1-17. London: Dent \& Sons.

\section{Ardener, Shirley}

1993 Introduction: The Nature of Women in Society. In: Shirley Ardener (ed.), Defining Females: The Nature of Women in Society; pp. 1-33. Oxford: Berg. (The Oxford Women Series, 1)

Balzer, Marjorie Mandelstam

1978 Strategies of ethnic survival: Interaction of Russians and Khanty (OSTIAK) in twentieth century Siberia. [unpubl. Ph.D. thesis, Bryn Mawr College]

\section{Behar, Ruth}

1993 Introduction. Women writing culture: another telling of the story of American anthropology. Critique of Anthropology 13: 307-325.

Berreman, Gerald D.

1968 Ethnography: Method and Product. In: James A. Clifton (ed.), Introduction to Cultural Anthropology: Essays in the Scope and Methods of the Science of Man; pp. 337-373. Boston: Houghton Mifflin Company.

\section{Bäckman, Louise}

1982 Female - Divine and Human. In: Åke Hultkrantz and Ørnulf Vorren (eds.), The Hunters: Their Culture and Way of Life; pp. 143-162. Troms $\emptyset$ : Universitetsforlaget. (Troms $\emptyset$ museums skrifter, 18)

\section{Code, Lorraine}

1991 What Can She Know?: Feminist Theory and the Construction of Knowledge. Ithaca: Cornell University Press.

Congressus octavus internationalis Fenno-Ugristarum

1996 Congressus octavus internationalis Fenno-Ugristarum, Jyväskylä 10.-15.8.1995; pars 6: Etnologia \& folkloristica. Ed. by Heikki Leskinen, Risto Raittila and Tónu Seilenthal. Jyväskylä.

Czaplicka, M. A.

1920 Samoyed. James Hastings (ed.), Encyclopædia of Religion and Ethics; vol. 11; pp. 172-177. Edinburgh: Clark.

\section{Englund, Harri}

1989 Kulttuurin käsitteellistäminen: Essee etnografian metodologiasta.

Fox, Jennifer Suomen antropologi / Antropologi i Finland 1: 20-33.

1987 The Creator Gods. Romantic Nationalism and the En-genderment of Women in Folklore. Journal of American Folklore 100 398: 563-572.

Green, Monica

1989 Women's Medical Practice and Health Care in Medieval Europe. Signs 14: 434-473.

Gross, Rita M.

1996 Feminism and Religion: An Introduction. Boston: Beacon Press.

Gröndahl, Satu M.

1997 Den ofullkomliga traditionen: Bilden av Ingermanlands kvinnliga runotradition. Stockholm: Almqvist \& Wiksell International. (Studia Uralica Upsaliensia, 27) 


\section{Haavio, Martti}

1952 Väinämöinen: Eternal Sage. Helsinki: Suomalainen Tiedeakatemia. (FF Communications, 144)

1985 Viimeiset runonlaulajat. Porvoo: WSOY. [1943]

\section{Hakulinen, Lauri}

1924 Opas suomen kielen murteiden sanavarain kerääjille. Suomi 5, 3: 140.

\section{Heikkinen, Kaija}

1992 Women, Marginality and the Manifestation of Everyday Life. A Study of the Present-day Feasts of the Veps and the Mari (in Russia). Ethnologia Fennica 20: 5-17.

\section{Hirdman, Yvonne}

1988 Genussystemet: Reflexioner kring kvinnors sociala underordning. Kvinnovetenskaplig tidskrift 3: 49-63.

\section{Harva, Uno}

1910 Naisen seremoniallisen epäpyhyyden alkuperä. By Uno Holmberg. Valvoja 11: 623-628.

1914 Tsheremissien uskonto. By Uno Holmberg. Provoo: WSOY. (Suomensuvun uskonnot, 5)

1918 Priest, Priesthood (Ugro-Finnish). By Uno Holmberg. In: James Hastings (ed.), Encyclopædia of Religion and Ethics; vol. 10; pp. 3356. Edinburgh: Clark.

1942 Mordvalaisten muinaisuskonto. Porvoo: WSOY. (Suomensuvun uskonnot, 6)

1952 Die Religiösen Vorstellungen der Mordwinen. Helsinki: Suomalainen tiedeakatemia. (FF Communications, 142)

1964 The Mythology of All Races; vol. 4: Finno-Ugric, Siberian. By Uno Holmberg. New York: Cooper Square Publichers.

1996 Lapparnas religion. Uppsala: Centre for Multiethnic Research. (Uppsala Multiethnic Papers, 10) [1915]

\section{Honko, Lauri}

1968 De finsk-ugriske folks religion. In: Jes Peter Asmussen and Jørgen Læssøe (eds.), Illustreret Religionshistorie; vol. 1; pp. 147-191. København: Gad.

1969-70 Uno Harva (1882-1949). Arv: Journal of Scandinavian Folklore 25-26: 57-66.

1978 The Ingrian Lamenter as Psychopomp. Temenos 14: 79-96.

1987 Finno-Ugric Religions: An Overview. In: Mircea Eliade (ed.), The Encyclopedia of Religion; vol. 5; pp. 330-340. New York: Macmillan.

I. $\mathbf{M}$.

1913 Pekka Koistinen. In: Erikoisia ihmisiä 4. Kotiseutu: 4: 6-8.

Järvinen, Irma-Riitta

1980 Nastja Rantsi tutkijan ja yhteisön kuvaamana. In: Pekka Laaksonen (ed.), Kertojat ja kuulijat; pp. 136-144. Helsinki: SKS. (Kalevalaseuran vuosikirja, 60)

Karjalainen, Kustaa Fredrik

1921 Die Religion der Jugra-Völker; vol. 1. Helsinki: Suomalainen tiede- 
akatemia. (FF Communications, 41)

1927 Die Religion der Jugra-Völker; vol. 3. Helsinki: Suomalainen tiedeakatemia. (FF Communications, 63)

1983 Ostjakit: Matkakirjeitä Siperiasta 1898-1902. By K. F. Karjalainen. Helsinki: SKS. (Suomalaisen kirjallisuuden seuran toimituksia, 394)

Karjalan kommuuni

1922 Karjalan kommuuni No. 85. Petroskoi.

Keinänen, Marja-Liisa

1998 Some Remarks on Women's Religious Traditionalism in the Soviet Karelia. In: Sölve Anderzén and Roald Kristiansen (eds.), Ecology of Spirit: Cultural Plurality and Religious Identity in the Barents Region; pp. 190-202. Umeå: Department of Religious Studies, Umeå University. (Alphabeta varia, Album Religionum Umense, 6)

King, Ursula

1995a Introduction: Gender and the Study of Religion. In: Ursula King (ed.), Religion and Gender; pp.1-38. Oxford: Blackwell.

1995b A Question of Identity: Women Scholars and the Study of Religion. In: Ursula King (ed.), Religion and Gender; pp. 219-244. Oxford: Blackwell.

King, Winston L.

1987 Religion In: Mircea Eliade (ed.) the Encyclopedia of Religion; vol. 12: 282-293. New York: Macmillan.

Korhonen, Mikko, Seppo Suhonen, and Pertti Virtaranta

1983 Sata vuotta suomen sukua tutkimassa: 100-vuotias Suomalais-ugrilainen seura. Helsinki: Weilin + Göös.

\section{Kosonen, Kirsti}

1988 Herroille marjassa. Havaintoja murresanaston keruusta ja kerääjistä 1920-1930-luvulla. In: Lea Laitinen (ed.), Isosuinen nainen: Tutkielmia naisesta ja kielestä; pp. 283-299. Helsinki: Yliopistopaino.

\section{Krohn, Julius}

1894 Suomen suvun pakanallinen jumalanpalvelus: Neljä lukua Suomen suvun pakanallista jumaluus-oppia. Helsinki: SKS. (Suomalaisen kirjallisuuden seuran toimituksia, 83, 1)

Krohn, Kaarle

1913 Finns (Ancient). In: James Hastings (ed.), Encyclopædia of Religion and Ethics; vol 6; pp. 23-26. Edinburgh: Clark.

1914 Suomalaisten runojen uskonto. Helsinki: SKS. (Suomalaisen kirjallisuuden seuran toimituksia, 137) (Suomensuvun uskonnot, 1)

\section{Leacock, Eleanor Burke}

1972 Introduction. In: Frederick Engels, The Origin of the Family, Private Property, and the State; pp. 7-67. New York: International Publishers.

1983 Interpreting the Origins of Gender Inequality: Conceptual and Historical Problems. Dialectical Anthropology 7: 263-284.

Lehtipuro, Outi

1968 Ilomantsi. In: Pentti Virtaranta et al (eds.), Karjalan laulajat; pp. 133-149. Helsinki: Kirjayhtymä. 
Lehtisalo, T.

1924 Entwurf einer Mythologie der Jurak-Samojeden. Mémoires de la Société Finno-Ougrienne LIII. Helsinki: Société Finno-Ougrienne.

\section{Lindemann, Mary}

1993 Professionals? Sisters? Rivals? Midwives in Braunschweig, 17501800. In: Hilary Marland (ed.), The Art of Midwifery: Early Modern Midwives in Europe; pp. 176-191. London: Routledge.

Moore, Henrietta L.

1988 Feminism and Anthropology. Cambridge: Polity Press.

Nenola, Aili

1986 Miessydäminen nainen: Naisnäkökulmia kulttuuriin. Helsinki: SKS. (Tietolipas, 102)

1993 Naisen ja miehen uskonto. In: Juha Pentikäinen ja Katja Pentikäinen (eds.), Uskonnot maailmassa; pp. 361-371. Porvoo: WSOY.

Niemi, A. R.

1921 Vienan läänin runonlaulajat ja tietäjät. Helsinki: SKS.

Ozorak, Elizabeth Weiss

1996 The Power, but not the Glory: How Women Empower Themselves Through Religion. Journal for the Scientific Study of Religion 35: 1729.

Paasonen, Heikki

1900 Kertomus Seuran mordvalaisten stipendiaattien keräysmatkain tuloksista. Helsinki. (Suomalais-ugrilaisen seuran aikakauskirja, 18)

1915 Mordvins. In: James Hastings (ed.), Encyclopædia of Religion and Ethics; vol. 7; pp. 842-847. Edinburgh: Clark.

Pelling, Margaret

1987 Medical Practise in Early Modern England: Trade or Profession? In: Wilfrid Prest (ed.), The Professions in Early Modern England. London: Croom Helm.

\section{Pentikäinen, Juha}

1987 Mari and Mordvin Religion. In: Mircea Eliade (ed.), The Encyclopedia of Religion; vol. 9; pp. 203-205. New York: Macmillan

Ravila, Paavo

1933 Suomalais-ugrilainen seura 1883-1933. Helsinki. (Suomalais-ugrilaisen seuran aikakauskiarja, 46)

Rombandeeva, E. I.

1968 Some Observances and Customs of the Mansi (Voguls) in Connection with Childbirth. In: V. Diószegi (ed.), Popular Beliefs and Folklore Tradition in Siberia; pp. 77-83. Budapest: Akadémiai.

Rosenhaft, Eve

1997 Kaksi sukupuolta - yksi historia?: Naishistoria, mieshistoria, sukupuolten historia ja niiden merkitys historiakäsityksellemme. Naistutkimus 2: 16-26.

Rydving, Håkan

1993 The End of Drum-Time: Religious Change among the Lule Saami, 1670s-1740s. Stockholm: Almqvist \& Wiksell International. (Historia Religionum, 12) 


\section{Saarinen, Aino}

1992 Feminist Research: An Intellectual Adventure? Tampere: University of Tampere, Research Institute for Social Sciences. (Julkaisuja / Tampereen yliopisto, Naistutkimusyksikkö, Sarja N, 4)

Sawin, Patricia E.

1990 Kalevalan naishahmot Lönnrotin hengentuotteina. In: Aili Nenola and Senni Timonen (eds.), Louhen sanat: Kirjoituksia kansanperinteen naisista; pp. 45-65. Helsinki: SKS. (Suomalaisen kirjallisuuden toimituksia, 520)

\section{Siikala, Anna-Leena}

1987 Finnic Religions. In: Mircea Eliade (ed.) The Encyclopedia of Religion. Vol. 5: 323-329. New York: Macmillan .

\section{Svalastog, Anna Lydia}

1997 Feministisk mytteori: En kulturanalytisk utfordring. In: Olof Sundqvist and Anna Lydia Svalastog (eds.), Myter och mytteorier; pp. 2154. Uppsala: Religionshistoriska avdelningen, Teologiska institutionen. (Religionshistoriska forskningsrapporter från Uppsala, 10)

\section{Tikka, Juho}

1913 Kaisa Pöyry. In: Erikoisia ihmisiä 3. Kotiseutu: 4: 4-6.

\section{Turunen, Risto}

1996 Syrjästä. Huomioita kahdesta perinnetieteen tutkijasta. In: Kaisu Kortelainen and Sinikka Vakimo (eds.), Tradition edessä: Kirjoituksia perinteestä ja kulttuurista; pp. 78-94. Joensuu: Suomen kansantietouden tutkijain seura.

\section{Utriainen, Terhi}

1995 Itkijänaisen paradoksi. Uskonnontutkimus, toinen ja tiedon asennot. Teologinen aikakauskirja $\mathrm{nr}$ 6: 531-539.

1998 Feminine and Masculine in the Study of Balto-Finnic Laments: Old and new questions. In: Satu Apo and Aili Nenola (eds.), Gender and Folklore: Perspectives on Finnish and Karelian Culture; pp. 175-200. Helsinki: SKS. (Studia Fennica, Folkloristica 4)

\section{Van Maanen, John}

1988 Tales of the Field: On Writing Ethnography. Chicago: University of Chicago Press.

\section{Vilkuna Asko}

1956 Das Verhalten der Finnen in "heiligen" /pyhä/ Situationen. Helsinki: Suomen Tiedeakatemia. (FF Communications, 164)

\section{Westermarck, Edvard}

1991 Tapojen historiaa: Kuusi akadeemista esitelmää pitänyt Turussa syksyllä 1911. Helsinki: SKS. [1913] 